\title{
Investigation of Physical Activity Enjoying and Quality of Life of Parents Who Have Mentally Disabled Children
}

\author{
${ }^{1}$ Mersin University, Department of Physical Education and Sports \\ ${ }^{2}$ Mersin University, Erdemli Vocational School, Department of Tourism Animation \\ ${ }^{3}$ Prof.Dr. Salih Öven Çolakoğlu Primary School \\ *Corresponding author: mersinilk@gmail.com
}

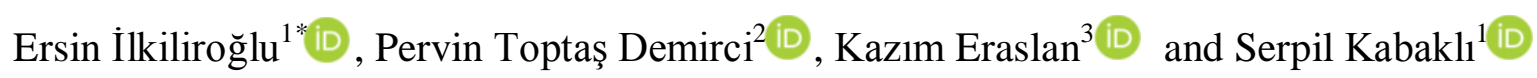

\begin{abstract}
In this study, it was aimed to investigate physical activity enjoying and quality of life In this study, it was aimed to investigate physical activity enjoying and quality of life the parents who have mentally retarded children. The study was to create by parents of female $(\mathrm{N}=72)$ and male $(\mathrm{N}=35)$ with mentally disability children in two special education center schools affiliated to the Ministry of National Education in Mersin. World Health Organization Quality of Life Scale-Short Form (WHOQOL-BREF) and Physical Activity Enjoyment Scale (PACES) were used to measure the quality of life of the parents. After the descriptive statistical procedures were applied in the analysis of the obtained data, $t$ test and ANOVA and Mann Whitney U and Kruskal Wallis tests were used to measure the differences between the variables. Significance was accepted as $\mathrm{p}<0.05$ According to the findings; As a result of the comparison of the likelihood of physical activity of the parents who have mentally retarded children according to gender, a high significant difference was found between women and men total score averages for women with negative thinking $(p<0.05)$. In our study, there was a significant correlation $(p<0,05, p<0,01)$ from physical activity likelihood of positive thinking subscale total scores and quality of life. Negative Thinking As a result of the relational analysis of total scores and quality of life levels, only low level of relationship with Psychological Health ( $p<0.05$ ) was determined. As a result of examining the health-related quality of life levels of the parents who have mentally retarded children according to age, a significant difference was observed between the mean scores of the age groups ( $p<0.05$ ). In conclusion, it can be said that the enjoyment of physical activity affects parents' health-related quality of life and there is a significant relationship between age and quality of life.
\end{abstract}

\section{Keywords}

Enjoying Physical Activity, Quality of Life, Parent, Disabled

\section{INTRODUCTION}

Participating in physical activity has many benefits for people. For this reason, it is extremely important for participants to enjoy and enjoy their activities in order to increase and maintain their participation in physical activity. Today, there are many studies showing that participation in physical activity decreases in young and adults. (Hsu et al., 2011; Ramirez et al., 2012). Physical activities, typically, have been shown to promote physical, mental and psychosocial health in parents with mentally retarded children (Toptaş Demirci and Demirci, 2018). The betwen reasons for this may be low motivation levels.Therefore, many researchers have emphasized the importance of participation at any age to develop positive attitudes towards physical activity (Patnode et al., 2011).

Enjoyment; It is a positive emotional state that reflects the feelings of fun, liking, pleasure and joy (Wankel, 1993) and has a positive relationship with the participation of parents with mentally disability children in physical activity 
(Sallis et al., 2000). Entertainment; adults with mentally disability children may be considered as the most important reason for their participation in physical activity and sports, and the lack of entertainment in the activity may prevent them from participating and continuing in physical activity. (Murcia et al., 2007; Carraro et al., 2008). Enjoyment is both an indicator and a product of participation in physical activity. While the enjoyment or enjoyment expected from physical activity increases the intention to participate in physical activity, positive emotional expectations ensure compliance and participation continue in physical activity (Mullen et al., 2011).

Since physical activity is one of the basic tools of having high quality of life; consciously spreading this idea, the level of interest and knowledge of families with mentally retarded children is effective in gaining a social dimension and raising healthy generations (Karakaş, G. ve Yaman, 2017 Although physical activity minimizes negative emotions, it is aimed to raise mentally healthy children. Therefore, it can be a strong reason for the child to gain self-confidence as well as healthy development and socialization. Improving the mother's health-related quality of life will improve the level of functional independence and quality of life, enabling better care for the child. (Vergili, Oktaş ve Koçulu, 2015).

An attempt to link quality of life with policies and practices for families with children with disabilities is a new paradigm in special education. The general quality of life variables of the families of parents with normal development it also applies to families of children exhibiting any type of disability. But, outside from the factors affecting the general outlook of the family, such as financial competence and sociocultural values, a significant impact on the family's quality of life can be mentioned (Meral, 2011). Having a disabled child affects the lives, emotions, thoughts and behaviors of family members negatively. Requires reorganization of parents' duties and activities, financial resources and all behaviors to cope with the needs of this new individual (Soresi et al., 2007: Akandere, Acar ve Baştuğ, 2009). Health problems such as anxiety, depression, emotional distress, low self-esteem and stress in families of children with disabilities are more advanced than families with normal children.
When all these factors are considered, it is thought that the perception of the family's physical activity and the rising quality of life will be positively reflected to their children. The fact that families are healthy in all respects will lead their children to grow up healthy. In this study, it was aimed to investigate physical activity enjoying and quality of life the parents who have mentally retarded children.

\section{MATERIALS AND METHODS}

In this section, the research model, universe and sample, data collection tools and related fields such as data analysis are examined.

\section{Research Model}

In this research, relational survey model was used. Screening models are research approaches aiming at describing a past or present situation as it exists (Karasar, 2019). Relational screening models are research models aiming to determine the presence or degree of co-change between two or more variables.

Research universe; composed parents of mentally retarded parents who are educated at the secondary and high school levels in Mersin. The sample of the study was formed by parents female $(\mathrm{N}=88)$ and Male $(\mathrm{N}=37)$, with mentally didsability children aged 10-15 years in schools in two special education centers in Mersin. Volunteers were included in the study. The participants were informed about the study and the purpose of the study was explained.

\section{Data Collection Tools}

The World Health Organization Quality of Life Scale-Short Form (WHOQOL-BREF), which was adapted to Turkish by Eser et al., (1999), was used to measure the quality of life of the parents. In addition, Physical Activity Enjoyment Scale (PACES) developed by Kendzierski and DeCarlo (1991) was used.

\section{Physical Activity Enjoyment Scale (PACES):}

The original Physical Activity Enjoyment Scale (PACES) was developed by Kendzierski and DeCarlo (1991). Subsequently, It was revised by Motl et al., (2001). The scale was translated into Turkish by Ergün (2013) and a validity and reliability study was conducted. Internal 
consistency coefficients were found between $\alpha=$ $0.85-0.90$. There were 15 items in the revised

$5=$ completely agree. The scale consists of two subscales in total. Indicating positive thoughts about doing exercise being active items (total 8 items) were collected in the first factor. The negative factors such as disliking and not having fun (7 items in total) were collected in the second factor. The lowest score that can be obtained from the scale is 15 and the highest score is 75 . The higher the score, the higher the likelihood of physical activity (Ergün, 2013).

\section{World Health Organization Life Quality Scale Short Form (WHOQOL-BREF):}

It was developed in 1996 by the World Health Organization (WHO) Quality of Life Group to assess how individuals perceive their own quality of life. Scale; It has WHOQOL-100 (long) consisting of 100 questions and WHOQOL-BREF (short) forms consisting of 26 questions selected from these 100 questions (Tekkanat, 2008). The Turkish validity and reliability study was performed by Eser et al. (1999) by the Short Form (WHOQOL-BREF) was used. Scale physical space, mental space, social space, environmental TR generated by the addition of a problem the environmental field and Turkish adaptation (Turkey) from the field consists of 5 subdimensions and 27 questions to be. In the scale, questions 3, 4, 26 and 27 are scored by reverse coding.

\section{Statistical Analysis}

All statistical analyzes were performed with SPSS version 22.0. Data were removed from extreme values in physical activity enjoyment and quality of life analyzes. Normality tests were performed. In the case of normal distribution between groups, t-test and ANOVA were used and Post-hoc LSD was used for binary comparisons. Mann - Whitney U and Kruskal Wallis Tests were used if the data were not distributed normally. The normality test was conducted to examine the relationship between the participants' PACES and WHOQOL-BREF scores, and the data were not distributed normally and Spearman correlation analysis was used to investigate the relationship. Significance was accepted as $\mathrm{p}<0.05$. scale. Answers with 5 ratings; $1=$ I disagree at all,

\section{RESULTS}

According to gender; comparison of the level of enjoyment from physical activity of parents with mentally retarded children in terms of positive thoughts, female $(\mathrm{N}=72, \overline{\mathrm{X}}=32.92 \pm$ 4.62) and male $(\mathrm{N}=35, \overline{\mathrm{x}}=31.51 \pm 4.65)$ total scores there was no difference between the mean (p> 0.05). Mean score of negative thoughts between female $(\mathrm{N}=72, \overline{\mathrm{X}}=28.99 \pm 4.58)$ and male $(\mathrm{N}=35, \overline{\mathrm{x}}=26.70 \pm 4.48)$, a significant difference was found against women ( $\mathrm{p}<0.05$ ). According to gender; There was no significant difference ( $p>0.05$ ) between the health-related quality of life comparison of the average score of parents with mentally retarded children (Table 1).

Parents with mentally retarded children; As a result of the comparison of average scores according to education levels, only in the environment variable; A significant difference ( $p$ $<0.05$ ) was found between the mean scores of secondary school $(\overline{\mathrm{X}}=0.53 \pm 0.19)$ and high $\operatorname{school}(\overline{\mathrm{X}}=0.63 \pm 0.13)$ (Table 2).

According to their age; as a result of comparison of body mass index of parents with mentally retarded children; 20-29 $(\mathrm{N}=25, \overline{\mathrm{x}}=$ $23,22 \pm 3,32)$ and 50-65 ( $=16, \overline{\mathrm{x}}=27,12 \pm$ $4,41)$ age range and 40-49 $(\mathrm{N}=52, \overline{\mathrm{x}}=24.72 \pm$ 4.07) and 50-65 $(\mathrm{N}=16, \overline{\mathrm{X}}=27.12 \pm 4.41)$ age ranges were found to be significantly different ( $\mathrm{p}$ $<0.05$ ) (Table 3).

In our study, no difference was found between the BMI comparisons of male parents according to their age ( $p>0.05)$. As a result of comparison of BMI and age of female parents; 20 $29(\overline{\mathrm{X}}=22.91 \pm 0.70)$ and $30-39(\overline{\mathrm{X}}=25.58 \pm$ $0.65)$ years of age $(\mathrm{P}=0.021) ; 20-29(\overline{\mathrm{X}}=22.91 \pm$ $0.70)$ and $50-65(\bar{X}=27.51 \pm 0.89)$ years of age $(p$ $=0.004)$; A significant increasing difference was found between the ages of $40-49(\bar{X}=27.51 \pm$ $0.89)$ and $50-65(\bar{X}=27.51 \pm 0.89)$ (Table 4).

According to the age of parents with mentally retarded children; as a result of comparing physical activity enjoyment levels there was no significant difference $(\mathrm{p}>0.05)$ (Table 5).

As a result of the examination of healthrelated quality of life levels of parents with mentally retarded children, according to age; in the field of general health (20-29 to 40-49 and 5065, 30-39 to 40-49), In the field of Physical Health 
(20-29 to 40-49), Psychological (30-39 to 40-49) age, Social Relations (between 30-39 and 40-49 and 50-65), environmental Area (30-39 to 50-65)

Parents with mentally retarded children ( $\mathrm{N}=111)$, according to the relationship between physical activity, positive thought total scores and quality of life; there were significant moderate level relationships with Physical Health $(r=0.37$, $\mathrm{p}<0.01)$, low level relationships with Psychological Health $(\mathrm{r}=028, \mathrm{p}<0.01)$, low level relationships with Social Relations $(\mathrm{r}=0.20$, $\mathrm{p}<0.05)$ and low level relationship with BREF Total $(r=0,29, p<0.01)$. As a result of the relational analysis of the total scores of negative thoughts of significant difference was found between the ages $(\mathrm{p}<0.05)$ (Table 6).

physical activity enjoyment of parents with mentally retarded children, only a significant low level relationship with Psychological Health was found $(\mathrm{r}=028, \mathrm{p}<0.05)$ (Table 7).

While there was no significant relationship between the mean scores of body mass index and the total score average of negative thoughts about physical activity enjoyment $(\mathrm{r}=-0.14 \mathrm{p}>0.05)$, there was a significant negative correlation between the mean of positive thinking total scores $(\mathrm{r}=-0.27 \mathrm{p}<0.01)($ Table 8$)$.

Table 1. Parents With Mentally Disability Children Comparison According to Gender

\begin{tabular}{|c|c|c|c|c|c|}
\hline & ender & $\mathrm{N}$ & $\square$ & $\mathrm{Sd}$ & $p$ \\
\hline \multicolumn{6}{|c|}{ Physical Activity Enjoyment Scale: Sub-dimensions } \\
\hline \multirow{2}{*}{ Positive Thoughts } & Females & 72 & 32,92 & 4,617 & \multirow{2}{*}{0,13} \\
\hline & Males & 35 & 31,51 & 4,655 & \\
\hline \multirow{2}{*}{ Negative Thoughts } & Females & 72 & 28,99 & 4,583 & \multirow{2}{*}{$* 0,01$} \\
\hline & Males & 35 & 26,69 & 4,484 & \\
\hline \multicolumn{6}{|c|}{ World Health Organization Life Quality Scale: Sub-dimensions } \\
\hline \multirow{2}{*}{ General Health } & Females & 72 &, 5556 &, 19443 & \multirow{2}{*}{0,81} \\
\hline & Males & 35 & ,5679 &, 18023 & \\
\hline \multirow{2}{*}{ Physical Health } & Females & 72 & ,6453 & , 16485 & \multirow{2}{*}{0,91} \\
\hline & Males & 35 & ,6520 & , 14760 & \\
\hline \multirow{2}{*}{ Psychological Health } & Females & 72 & ,5994 &, 13460 & \multirow{2}{*}{0,90} \\
\hline & Males & 35 & ,6033 & , 10989 & \\
\hline \multirow{2}{*}{ Social Relations } & Females & 72 & ,6204 & , 18176 & \multirow{2}{*}{0,61} \\
\hline & Males & 35 & ,6429 & 13493 & \\
\hline \multirow{2}{*}{ Environmental Health } & Females & 72 & ,5794 & , 16343 & \multirow{2}{*}{0,62} \\
\hline & Males & 35 & ,6375 & , 13773 & \\
\hline \multirow{2}{*}{ Total Bref Score } & Females & 72 & 92,31 & 12,77192 & \multirow{2}{*}{0,34} \\
\hline & Males & 35 & 94,65 & 9,78577 & \\
\hline \multirow{2}{*}{ BMI } & Females & 72 & 24,59 & 3,69 & \multirow{2}{*}{0,20} \\
\hline & Males & 35 & 25,34 & 4,30 & \\
\hline
\end{tabular}

$\mathrm{p}<0,05$, Body Mass Index (BMI) 
Table 2. Comparison of Parents with Mentally Retarded Children According to Education Level.

\begin{tabular}{|c|c|c|c|c|c|}
\hline & Education & & $\overline{\mathbf{x}}$ & Sd & $p$ \\
\hline \multicolumn{6}{|c|}{ Physical Activity Enjoyment Scale: Sub-dimensions } \\
\hline \multirow{2}{*}{ Positive Thoughts } & Middle School & 42 & 31,9 & 4,90 & \multirow{2}{*}{0,76} \\
\hline & High school & 70 & 32,21 & 5,16 & \\
\hline \multirow{2}{*}{ Negative Thoughts } & Middle School & 42 & 28,10 & 4,81 & \multirow{2}{*}{0,51} \\
\hline & High school & 70 & 27,24 & 5,48 & \\
\hline \multicolumn{6}{|c|}{ World Health Organization Life Quality Scale: Sub-dimensions } \\
\hline \multirow{2}{*}{ General Health } & Middle School & 42 & 0,55 & 0,20 & \multirow{2}{*}{0,53} \\
\hline & High school & 70 & 0,56 & 0,18 & \\
\hline \multirow{2}{*}{ Physical Health } & Middle School & 42 & 0,62 & 0,16 & \multirow{2}{*}{0,21} \\
\hline & High school & 70 & 0,66 & 0,14 & \\
\hline \multirow{2}{*}{ Psychological Health } & Middle School & 42 & 0,59 & 0,13 & \multirow{2}{*}{0,70} \\
\hline & High school & 70 & 0,60 & 0,12 & \\
\hline \multirow{2}{*}{ Social Relations } & Middle School & 42 & 0,60 & 0,17 & \multirow{2}{*}{0,33} \\
\hline & High school & 70 & 0,61 & 0,17 & \\
\hline \multirow{2}{*}{ Environmental Health } & Middle School & 42 & $\mathbf{0 , 5 3}$ & $\mathbf{0 , 1 9}$ & \multirow{2}{*}{$\mathbf{0 , 0 1}$} \\
\hline & High school & 70 & 0,62 & $\mathbf{0 , 1 3}$ & \\
\hline \multirow{2}{*}{ Total Bref Score } & Middle School & 42 & 90 & 13,5 & \multirow{2}{*}{0,12} \\
\hline & High school & 70 & 94 & 10,5 & \\
\hline \multirow{2}{*}{ BMI } & Middle School & 42 & 25,84 & 3,96 & \multirow{2}{*}{0,93} \\
\hline & High school & 70 & 24,53 & 4 & \\
\hline
\end{tabular}

$\mathrm{p}<0,05$, Body Mass Index (BMI)

Table 3. Comparison of Body Mass Index by Age of Parents with Mentally Retarded Children.

\begin{tabular}{cccccc}
\hline & Age & $\mathbf{N}$ & $\overline{\mathbf{x}}$ & $\mathbf{S d}$ & $\boldsymbol{p}$ \\
\hline \multirow{6}{*}{$20-29$} & 25 & 23,22 & 3,32 & \multirow{2}{*}{0,13} \\
& $30-39$ & 30 & 25,57 & 3,13 & \\
\hline $20-29$ & 25 & 23,22 & 3,32 & \multirow{2}{*}{0,11} \\
& $40-49$ & 52 & 24,72 & 4,07 & \\
$\mathbf{B M I}$ & $\mathbf{2 0 - 2 9}$ & 25 & $\mathbf{2 3 , 2 2}$ & 3,32 & \multirow{2}{*}{$\mathbf{0 0 0}$} \\
& $\mathbf{5 0 - 6 5}$ & 16 & $\mathbf{2 7 , 1 2}$ & 4,41 & \\
\cline { 2 - 6 } & $30-39$ & 30 & 25,57 & 3,13 & \multirow{2}{*}{0,31} \\
& $40-49$ & 52 & 24,72 & 4,07 & \\
& $30-39$ & 30 & 25,57 & 3,13 & \multirow{2}{*}{0,07} \\
& $50-65$ & 16 & 27,12 & 4,41 & \\
& $\mathbf{4 0 - 4 9}$ & 52 & $\mathbf{2 4 , 7 2}$ & 4,07 & \multirow{2}{*}{$\mathbf{0 2}$} \\
& $\mathbf{5 0 - 6 5}$ & 16 & $\mathbf{2 7 , 1 2}$ & 4,41 & \\
\hline
\end{tabular}

$\mathrm{P}<0,05$, Body Mass Index $(\mathrm{BMI})$ 
Table 4. Comparison of Parents with Mentally Retarded Children by Age and Gender.

\begin{tabular}{|c|c|c|c|c|c|c|}
\hline \multirow{9}{*}{ Age } & & Gender & $\mathrm{N}$ & $\overline{\mathbf{x}}$ & $\mathrm{Sd}$ & $\mathrm{p}$ \\
\hline & \multirow[t]{2}{*}{$20-29$} & Famales & 20 & 22,91 & 0,70 & \multirow[t]{2}{*}{0,36} \\
\hline & & Males & 5 & 24,45 & 1,91 & \\
\hline & \multirow[t]{2}{*}{$30-39$} & Famales & 19 & 25,58 & 0,65 & \multirow[t]{2}{*}{0,98} \\
\hline & & Males & 11 & 25,56 & 1,12 & \\
\hline & \multirow[t]{2}{*}{$40-49$} & Famales & 32 & 24,44 & 0,75 & \multirow[t]{2}{*}{0,38} \\
\hline & & Males & 19 & 25,47 & 0,86 & \\
\hline & \multirow[t]{2}{*}{$50-65$} & Famales & 7 & 27,51 & 0,89 & \multirow[t]{2}{*}{0,77} \\
\hline & & Males & 9 & 26,82 & 1,90 & \\
\hline
\end{tabular}

$\mathrm{p}>0.05$

Table 5. Comparison of Physical Activity Enjoyment Levels of Acordin to Age Parents with Mentally Retarded Children.

\begin{tabular}{lccccc}
\hline \multicolumn{1}{c}{ PACES Sub-Dimensions } & Age & $\mathbf{N}$ & $\overline{\mathbf{x}}$ & $\mathbf{S d}$ & $\boldsymbol{p}$ \\
\hline \multirow{3}{*}{ Positive Thoughts } & $20-29$ & 12 & 31,50 & 0,90 & \\
\cline { 2 - 5 } & $30-39$ & 30 & 33,23 & 4,17 & \multirow{2}{*}{0,33} \\
\cline { 2 - 5 } & $40-49$ & 53 & 30,45 & 7,00 & \\
\cline { 2 - 5 } Negative Thoughts & $50-65$ & 13 & 30,69 & 2,57 & \\
& $20-29$ & 12 & 28,92 & 3,63 & \\
& $30-39$ & 30 & 27,43 & 6,08 & \multirow{2}{*}{0,33} \\
\cline { 2 - 5 } & $40-49$ & 53 & 26,08 & 5,90 & \\
\cline { 2 - 5 } & $50-65$ & 13 & 28,15 & 3,48 & \\
\hline
\end{tabular}

$\mathrm{P}>0,05$

Table 6. Examination of Health Related Quality of Life Levels of Parents with Mentally Retarded Children According to Age.

\begin{tabular}{llllll}
\hline $\begin{array}{c}\text { WHOQOL- BREF } \\
\text { Sub-Dimensions }\end{array}$ & Age & N & $\overline{\mathbf{x}}$ & Sd & p \\
\hline \multirow{4}{*}{ General Health } & $20-29$ & 23 & 0,65 & 0,12 & \multirow{2}{*}{0,00} \\
& $40-49$ & 53 &, 048 & 0,18 & \\
\cline { 2 - 6 } & $20-29$ & 23 & 0,65 & 0,12 & \multirow{2}{*}{0,00} \\
& $50-65$ & 16 & 0,47 & 0,19 & \\
\cline { 2 - 6 } & $30-39$ & 31 & 0,62 & 0,20 & \multirow{2}{*}{0,00} \\
\hline \multirow{2}{*}{ Physical Health } & $40-49$ & 53 &, 048 & 0,18 & \\
\hline \multirow{2}{*}{ Psychological Health } & $20-29$ & 22 & 0,71 & 0,11 & \multirow{2}{*}{0,00} \\
& $40-49$ & 53 & 0,60 & 0,15 & \\
\hline \multirow{2}{*}{ Social Relations } & $30-39$ & 29 & 0,65 & 0,09 & \multirow{2}{*}{0,00} \\
& $30-49$ & 52 & 0,55 & 0,14 & \\
\hline \multirow{2}{*}{ Environmental Health } & $30-39$ & 31 & 0,70 & 0,16 & \multirow{2}{*}{0,00} \\
& $40-49$ & 52 & 0,56 & 0,20 & \\
\hline
\end{tabular}

$\mathrm{P}<0,05, \mathrm{P}<0,01$ 
Table 7. Relationship between Physical Activity Enjoyment Score and Health Related Quality of Life Levels of Parents with Mentally Retarded Children

\begin{tabular}{lcccccc}
\hline Sub-Dimensions & $\begin{array}{c}\text { General } \\
\text { Health }\end{array}$ & $\begin{array}{c}\text { Physical } \\
\text { Health }\end{array}$ & $\begin{array}{c}\text { Psychological } \\
\text { Health }\end{array}$ & $\begin{array}{c}\text { Social } \\
\text { Relations }\end{array}$ & $\begin{array}{c}\text { Environmental } \\
\text { Health }\end{array}$ & $\begin{array}{c}\text { BREF } \\
\text { Total }\end{array}$ \\
\hline Positive Thoughts & 0,16 & $\mathbf{0 , 3 7 * *}$ & $\mathbf{0 , 2 8 * *}$ & $\mathbf{0 , 2 0 *}$ & 0,15 & $\mathbf{0 , 2 9 * * *}$ \\
\hline Negative Thoughts & 0,58 & 0,18 & $\mathbf{0 , 2 8 *}$ & 0,16 & 0,05 & 0,18 \\
\hline
\end{tabular}

$* * \mathrm{p}<0,01 * \mathrm{p}<0,05$

Table 8. The Relationship Between Body Mass Index and Physical Activity Enjoyment Score Levels of Parents with Mentally Retarded Children

\section{BMI}

\begin{tabular}{lccc}
\cline { 2 - 4 } Positive Thoughts & $\mathbf{r}$ & $\overline{\mathbf{x}}$ & Sd \\
\cline { 2 - 4 } & $-0,14$ & 27,37 & 5,32 \\
\cline { 2 - 4 } Negative Thoughts & $\mathbf{- 0 , 2 6 8 *}$ & 32,06 & 4,98 \\
\hline$* \mathrm{p}<0,01$ & & &
\end{tabular}

\section{DISCUSSION}

In this study, according to gender, age and education; No significant difference was found between male and female individuals when BMI, physical activity enjoyment and health-related quality of life were compared. The parents who have mentally retarded children were found to have a significant relationship with the physical activity enjoyment Positive Thought Total scores and quality of life levels. Negative Thinking As a result of the relational analysis of total scores and quality of life levels, only a low level of relationship was found with Psychological Health. As a result of examining the health-related quality of life levels of parents with mentally retarded children according to age, a significant difference was found between the mean scores of age groups. Positive or negative feelings that occur within the family's own nature can affect people and play a role in their quality of life. The quality of family life evaluated in this context is meeting the needs of family members, living together as a family is a way of reaching and having target that are meaningful for family members (Boylu ve Terzioğlu, 2007).
Let alone the idea of having a disabled child "How can it be met in society?" let aside the thought; it can be said that it is a difficult process for parents to accept and overcome this situation. Because living with a disabled child changes the plans of the family members, their projects and expectations about the future (Aysan ve Özben, 2007). The inconsistency between family expectation and the reality of family functionality leads to poor mental health in parents (Johnson et al., 2011). Since physical activity is one of the basic tools of having high quality of life; In order to improve the quality of life and many psychological factors, parent and disabled child may turn away from the problems they experience both in the family and in the community by turning to different activities (Aras et al., 2014; Demirci et al., 2018).

In our study according to gender; parents with mentally retarded children; As a result of the comparison of the levels of liking of physical activity in terms of positive thoughts, there was no difference between the mean scores of men and women, while there was a high significant 
difference in negative thinking against women. retarded children have lower physical health and quality of life than mothers with normal developmental children (Allik et al., 2006; Benjak, 2011; Aras et al., 2014; Eapen and Guan, 2016). Upgrading a child with a disability or autism can affect the adaptation skills, characteristics, perceived family life quality, psychological health, and family's sense of consistency (Tung et al., 2014). At this point, emotional and social support to families is vital for improving emotional health and quality of life.

In the researches, life quality of parents who have mentally retarded children is developing as an important field (Bertelli, Bianco, Rossi, Scuticchi and Brown, 2011). Researchers argue that parents of children with disabilities are more vulnerable to physical and mental problems and have a lower quality of life (Şıpoş, Predescu, Mureşan and Iftene, 2012). Dahan-Oliel, Shikako-Thomas, and Majnemer (2012) have reported in many studies that there are findings that both leisure-time children and their families participate in everyday activities at home, at school or in the community to improve health and quality of life. Likewise, not participating in activities or decreasing participation has resulted in a decrease in the quality of life.

As a result; It can be said that the physical activity enjoyment affects the health-related quality of life of parents and there is a significant relationship between age and quality of life. Raising awareness and directing families can be considered as the first step to enable them to live as healthier families and to raise healthy individuals. Physical activity levels and quality of life of parents with mentally retarded children will contribute to the field of special education and will be the source of planning and program development activities for families of children with disabilities (social services and social assistance, educational services, family education programs, encouragement of participation in physical activity), In the following process, it is thought that it will contribute theoretically to the researches on the subject and guide the practitioners.
Studies have shown that families with mentally

\section{REFERENCES}

Akandere, M., Acar, M., Baştuğ, G. (2009). Investigating The Hopelessness And Life Satisfaction Levels of The Parents With Mental Disabled Child, Journal of Selçuk University Social Sciences Institute, Issue: 22, 23-32.

Allik, H., Larsson, J. \& Smedje, H. (2006). Healthrelated quality of life in parents of schoolage children with asperger syndrome or highfunctioning autism. Health and Quality of Life Outcomes. 4: 1.

Aras, I., Stevanovic, R., Vlahovic, S., Stevanovic, S., Kolaric, B. \& Kondic, L. (2014). Health related quality of life in parents with speech and hearing impairment. International Journal of Pediatric Otorhinolaryngology. 78: 323-329.

Aysan, F. ve Özben, Ş. (2007). Research on quality of life of parents having disabled children, Journal of Dokuz Eylül University Buca Educational Faculty, Issue:22,pp. 1-6.

Benjak, T. (2011). Subjective quality of life for parents of children with autism spectrum disorders inCroatia. Applied Research in Quality of Life. 6: 91-102.

Bertelli, M., Bianco, A., Rossi, M., Scuticchio, D., Brown, I. (2011). "Relationship between individual quality of life and family quality of life for people with intellectual disability living in Italy", Journal of Intellectual Disability Research, Issue: 55, C. 12, pp. 1136-1150.

Boylu, A. ve Terzioğlu, G. (2007). Investigation of some objective and subjective indicators affecting the quality of life of families. T. C. Prime Ministry General Directorate of Family and Social Research Publications. Ankara.

Carraro, A., Young, A. C. \&Robazzo, C. (2008). A contribution to the validation of the physical activity enjoyment scale in an Italian sample, Social Behavior and Personality, 36 (7), 911918.

Dahan-Oliel, N., Shikako-Thomas, K. \& Majnemer, A. (2012). Quality of life and leisure participation in children with neurodevelopmental disabilities: a thematic 
analysis of the literature. Qual Life Res, 21:427-439.

Demirci, N., Yıldırım, İ., Toptas Demirci, P., Ersöz, Y. (2018). Why Should We Do Physical Activity? More Active People For A Healthier World, International Journal of Disabilities Sports and Health Science, Issue $1(2) ; 1-14$

Eapen, V. \& Guan, J. (2016). Parental quality of life in autism spectrum disorder: Current status and future directions. Acta Psychopathol. 2:1.

Eser, E., Fidaner, H., Fidaner, C., Elbi, H. \& Göker, E. (1999). Psychometric properties of WHOQOL-100 and WHOQOL-Bref. Journal 3p, 8 (4), 23-40.

Ergün, S. (2013). Relationship Between Enjoying Exercise and Physical Activity in School Age Children, Istanbul: Marmara University, Institute of Health Sciences, Public Health Nursing, Master Thesis.

Hsu Y., Chou C., Nguyen-Rodriguez S.T, McClain A.D, Belcher B.R, and Spruijt-Metz D. (2011) Influences of social support, perceived barriers, and negative meanings of physical activity on physical activity in middle school students, Journal of Physical Activity and Health, 8, pp.210 -219.

Johnson, N., Frenn, M., Feetham, S. \& Simpson, P. (2011). Autism spectrum disorder: Parenting stress, family functioning and health-related quality of life. Families, Systems and Health. 29, pp.232-252.

Karakaş, G. \& Yaman, Ç. (2017). "Examination of the quality of life according to the physical activity status of parents who have disabled individual, Journal of Human Sciences, 14(1), pp. 724-737.

Karasar, N. (2019). Scientific Research Method: Concepts Principles Techniques Ankara: Nobel Academic Publishing.

Kendzierski, D., \&DeCarlo, K. L. (1991). Physical activity enjoyment scale: Two validation studies. Journal of Sport Exercise Psychology, 14 (9), 50-64.

Meral, B.F. (2011) Investigation of Family Life Quality Perceptions of Mothers with Developmental Disabilities, (Unpublished doctoral thesis), Anadolu University / Institute of Educational Sciences, Eskişehir.

Mirzeoğlu, A. D. \& Çoknaz, D. (2014). The validity and reliability study of physical activity liking scale-short form for Turkish children and adolescents. International Journal of Human Sciences, Issue:11(1),pp. 672-687.

Mullen, P. S., Olson E.A, Phillips S.B., Szao A.N. ve ark. (2011). Measuring enjoyment of physical activity in older adults: invariance of the physical activity enjoyment scale (Paces) across groups and time, International Journal of Behavioral Nutrition and Physical Activity, 8 (1), 103.

Murcia J.A.M., Blanco M.L., Galindo C.M., Coll D.G. (2007). Effects of the gender, the age and the practise frequency in the motivation and enjoyment of the physical exercise, Fitness Performance J, 6,3, 140-146.

Patnode C.D, Lytle L.A, Erickson D.J., Sirard J.R., Daheia J. Barr-Anderson D.J., Story M. (2011). Physical activity and sedentary activity patterns among children and adolescents: a latent class analysis approach, Journal of Physical Activity and Health, 8, $457-467$.

Ramirez E., Kulinna P.H., Donetta Cothran D. (2012). Constructs of physical activity behaviour in children: The usefulness of Social Cognitive Theory, Psychology of Sport and Exercise, 13, 303-310.

Sallis, J.F., Prochaska, J.J. \& Taylor, W.C. (2000) A review of correlates of physical activity of children and adolescents. Medicine and Science in Sports and Exercise 32, 963-975.

Soresi, S., Nota, L., Ferrari, L. (2007). "Considerations on Supports That Can Increase the Quality of Life of Parents of Children With Disabilities", Journal of Policy and Practice in Intellectual Disabilities, Say1: 4, C. 4, 248-251.

Şıpoş, R., Predescu, E., Mureşan, G., Iftene, F. (2012) "The Evaluation of Family Quality of Life of Children with Autism Spectrum Disorder and Attention Deficit Hyperactive Disorder", Applied Medical Informatics, Issue: 30, C. 1, , 1-18.

Toptaş Demirci, P. and Demirci N. (2018). The Effects Of Game And Physical Activity Lessons In Children With Learning Disabilities, Kinesiologia Slovenica, 24, 3, 47-55.

Tung, L., Huang, C., Tseng, M., Yen, H., Tsai, Y., Lin, Y., Chen, K. (2014). Correlates of health- related quality of life and the 
perception of its importance in caregivers of children with autism. Research in Autism Spectrum Disorders. 8: 1235-1242.

Vergili, Ö., Oktaş, B., Koçulu, E. (2015). Examination of the quality of life according to the physical activity status of parents who have disabled individual, Hacettepe University Faculty of Health Sciences Journal. 1 (1): 1-7.

Wankel, L. M. (1993). The importance of enjoyment to adherence and psychological benefits from physical activity, International Journal of Sport Psychology, 24, 151-169. 